commented that in mental health we had our share of "loonies"). This is precisely the technique used not infrequently in the Soviet Union, the technique which is rightly condemned by the reviewer and Mr Levin.

Models are factitious, giving delusions of reality, but lenses always give real views, albeit sometimes distorted or deflected.

J A MuIr Gray

Oxfordshire Area Health
Authority (Teaching),

Authority (Treact
Health Offices,

Health
Oxford

' Siegler, M, and Osmond, M, Models of Madness, Models of Medicine. London, Macmillan, 1974

SIR,-As an outsider to both psychiatry and psychology I have been looking forward for some time to finding a serious professional comment on $G$ Baruch and A Treacher's Psychiatry Observed, ${ }^{1}$ which I read on its appearance earlier this year with mixed feelings of enjoyment and irritation. The review which eventually appeared in the $B M \mathcal{F}$ (16 September, p 821) over the name of Dr Henry R Rollin was a poor reward for my patience.

I am far from being a revolutionary and am not even a socialist in any serious sense, but the fact that I have no enthusiasm for the "socialist transformation of society" sought by Baruch and Treacher does not blind me to the possible validity of some of the points they make. To spend a major part of a fairly long review doing little but carp at their distasteful ideology is a poor substitute for the substantive discussion of their actual arguments and the sober evaluation of the evidence they adduce to support them. No reader of Dr Rollin's notice would be likely to gather a clear impression (favourable or otherwise) of what the book actually asserts, beyond a few themes which your reviewer has chosen to attend to for no better reason than that he is irritated by what the authors say. As it happens I agree with Dr Rollin's implication that Baruch and Treacher often write as though the mere fact that they would have approached specific clinical problems in a different way from that adopted by consultant psychiatrists should be enough in itself to satisfy the reader that the consultants were wrong. But this is exactly the assumption that Dr Rollin makes in his own disagreements with the authors on such matters as the relation of politics to medicine and psychiatry, the role of consultants relative to that of psychologists and other paramedical workers, the value to be placed on drugs and other physical methods of treatment, and the social dimensions of psychiatric illness. Dr Rollin, like the authors he attacks, appears to believe that he has only to state his disagreement for the matter to be at an end. This is precisely the mandarin style that arouses so much antipathy (certainly not just among radicals) against the medical Establishment (Dr Rollin's word and capitalisation) as well as against the equally self-righteous mandarins of the left.

Particularly silly are Dr Rollin's remarks about the Soviet Union. Those who inhabit what he calls "the Marx, Trotsky, Mao triangle" are among the last people on earth to hold up Russia as a model for human society and it is culpably naive of your reviewer not to know this. I believe that the far left are themselves culpably naive in imagining that the terrible history of communism lacks major and appalling significance for any kind of revolutionary marxism and no doubt Dr
Rollin and I would be in agreement here. But it is pointless to use "that vast prison camp, the USSR" as a stick to beat the Trotskyists with. Some of them would regard that designation as rather mild.

Dr Rollin is so obsessed by the politics of his authors that it is enough for them to advocate any kind of change for your reviewer to condemn it. One does not need to be socialist, one hardly needs to be even a liberal, to believe (and to be able to argue one's belief) that there is room for far greater democracy in our health services. But because Baruch and Treacher want "democracy" (which admittedly they might define in rather strange ways) $\mathrm{Dr}$ Rollin must call it "anarchy" and finish his notice with a final tilt at Vanessa Redgrave's dismal little sect. I had hoped that debates in the medical profession were more informatively and relevantly conducted. Meanwhile neither Baruch nor Treacher, I think, need lose much sleep over this angry but intellectually vacuous review.

Department of Sociology, University of Bristol

Baruch, G, and Treacher, A, Psychiatry Observed.

London, Routledge and Kegan Paul, 1978.

***We sent a copy of this letter to Dr Rollin,

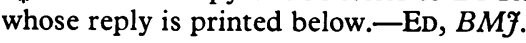

SIR,-Thank you for the opportunity of replying to Dr Hamnett's somewhat acid comments on my review of Baruch and Treacher's book. I am, however, just a little disconcerted because, on analysis, he agrees rather than disagrees with some at least of my major criticisms.

However, there is no gainsaying that not only does he not like much of what I wrote, but so personal are his remarks that it seems obvious that he doesn't like me either. It behoves me, therefore, to defend myself as best I can.

I am accused of intellectual vacuity. May I assure Dr Hamnett that I make no claim to being an intellectual, vacuous or otherwise. My doctorate is in medicine, not philosophy, let alone political philosophy. My concern, as a humble medical practitioner, is with the welfare and treatment of patients using whatever therapeutic tools are to hand.

I am accused of political naivety. Dr Hamnett may have a point. In my review I concede that "I am not particularly well versed in the various groups that make up the revolutionary socialist left." Dr Hamnett is obviously far better informed than I am, although I'm still not sure which political label he attaches to our authors. Not that I think that, for the purposes of my argument, it makes much difference.

Dr Hamnett by implication would have it that as a member of the medical Establishment, which I am, I cannot be a socialist. I am not, but it may surprise Dr Hamnett to learn that I once was. I was in fact raised in a fervently socialist household and as a child attended a socialist Sunday school. At the time of elections ours was the only house in the street to display posters supporting the socialist candidate; a tiny red island in a sea of Tory blue. I abandoned my socialist beliefs years ago mainly because I refused to be blinded any longer by doctrine añd insisted thereafter on keeping my political options open. With the dawn of reason I came also to appreciate the evergrowing corruption of the power the left had achieved and, as it grew, the corruption of the sort of socialism I had been brought up to believe in.

Dr Hamnett objects to my use of the word "anarchy" in describing the state of affairs obtaining in the Health Services today. Perhaps I should explain to him that I was appointed a consultant in the National Health Service in 1948 and that at that time there was no more enthusiastic advocate of that service than I was. It worked well to begin with. There were problems, of course, but it would have been unthinkable in the, say, 1950s or 1960s to jeopardise the welfare of patients by bringing to a halt operating theatres, casualty departments, laundries, and kitchens because of the irresponsible action of groups of hospital employees for their own selfish, political ends. If Dr Hamnett chooses to call this sort of action "democratic" and want more of it, then that is his prerogative.

I should add that two years ago I retired from the National Health Service as disillusioned and disenchanted as I had been when I abandoned socialism decades beforeand for the very same reasons.

Finally, I am accused of writing my review in anger. Dr Hamnett is darned right: I was furious.

Epsom, Surrey

Henry R Rollin

\section{PUVA treatment of psoriasis}

SIR,-We are grateful to Dr E J Land (2 September, $p$ 703) for pointing out the triplet energy level of 8-methoxypsoralen and agree that this precludes the direct photosensitisation of thymine dimerisation by 8 -methoxypsoralen in vitro. However, it is known that mutagenic changes can occur in the skin as a result of exposure to ultraviolet light in the region $300-320 \mathrm{~nm}^{1}$ and also in the course of PUVA treatment at $365 \mathrm{~nm},{ }^{2}$ so that thymine dimerisation in the single DNA strand, which is generally accepted as being the basis of mutagenesis, can be induced in vivo by wavelengths considerably longer than $295 \mathrm{~nm}$. These changes should theoretically be disallowed on the basis of the absorption of thymine itself, ${ }^{3}$ so that the biological mechanism must be of a rather more complex nature and the doubts about the safety of PUVA remain.

Martin Whitefield

Dermal Laboratories Ltd

Hitchin, Herts

H R HuDSON D HyatT

Department of Chemistry,

Polytechnic of North London, London N7

' Ramsay, C A, and Giannelli, F, British fournal of Dermatology, 1975, 92,49

${ }^{2}$ Ashwood-Smith, $M$ J, and Grant, E, British Medical Fournal, 1976, 1, 342. ${ }^{3}$ Setlow, R B, Science, 1966, 153, 379.

\section{Diagnosis of inflammatory bowel} disease

SIR,-Dr R J Dickinson and his colleagues (2 September, p 705) may have misunderstood a point in our letter (15 July, p 202). Our intention was not to suggest a cause-and-effect relationship between infective colitis and inflammatory bowel disease (IBD) but merely to stress that in the assessment of a patient presenting with bloody diarrhoea the clinician 
should be aware of the whole spectrum of possible causes of colonic inflammationinfective as well as non-infective ones.

We are most interested in their series of patients with "infective diarrhoea" who had negative stools. For some years now, in collaboration with Dr B C Morson and his colleagues at St Mark's Hospital, London, we have been studying patients presenting with bloody or persistent diarrhoea and we have become aware of a number of patients who cannot be categorised into any of the recognised types of colitis. For want of a better term we are using the name "transient colitis" to describe such cases. These patients present with diarrhoea (frequently bloody) of sudden onset, with the sigmoidoscopic and rectal biopsy changes of acute colitis and consistently negative stool cultures. The outcome is invariably satisfactory: the symptoms subside within a few days and follow-up so far has revealed no instance. of a relapse. In 172 patients with diarrhoeal states there were 34 patients who fell into this category. Histologically, some of these patients had the appearances of infective colitis; but others showed changes suggestive of IBD. We tend to take the view that these patients were suffering from an infective colitis, the negative bacteriology being due either to prior antibiotic therapy or to infection with organisms other than shigellae, salmonellae, or amoebae. The recent discovery of some campylobacter species as significant enteric pathogens is of considerable interest and may have accounted for some of these cases. A quarter of our patients with campylobacter diarrhoea had bloody diarrhoea and we have found evidences of colitis at sigmoidoscopy and biopsy in a number of these patients. It is interesting that four of these patients had rectal mucosal changes highly suggestive of IBD.

It seems likely that many patients labelled as having ulcerative colitis or colonic Crohn's disease on sigmoidoscopy and biopsy findings with negative bacteriology, but who have remained in complete remission since the initial attack, are in fact examples of "transient colitis," probably of infective aetiology. Therefore we fully endorse the view of $\mathrm{Dr}$ Dickinson and his colleagues that the diagnosis of IBD should not be made prematurely in view of its long-term therapeutic and social implications.

B MANDAL

A G IRONSIDE

Regional Department of Infectious

Disease

Monsall Hospital

Manchester

Department of Surgery,

University Hospital of South

Manchester,

Manchester

\section{Time and the consultation in general} practice

SIR,-Having read the interesting report by Dr K B Thomas (7 October, p 1000) I think his data capable of an alternative explanation. The majority of patients of the kind detailed in the study seen in general practice do not return within one month-they have selflimiting symptoms which disappear with or without, because of, or in spite of treatment. This is clearly shown in the table. Some patients do return, however, and it seems on examination of the data that there is a reduction of over $50 \%$ in patients who returned with the same or a different complaint in the patients in the "long no treatment" group. I postulate that Dr Thomas's results show that there are two groups of patients-the majority who attend once and a minority who do benefit from care and attention and a reasonable explanation of their symptoms.

How can we recognise this minority ? Until we do so I think that it will be very difficult to prove anything about the length of time of consultations, as data will be diluted by those for whom time does not seem to be a factor.

IAIN GILCHRIST

Bishop's Stortford, Herts

SIR,-Dr K B Thomas in his report "Time and the consultation in general practice" (7 October, p 1000) is using a statistical device designed to make sure that a positive association is not: shown to exist when none does exist. In other words it errs on the side of caution. The study does not prove that there may not be a positive association between length of consultation and number of return visits a month later-merely that none has been proved with the number of patients studied.

Taking the last two columns and lumping "the same complaint" and "different complaint" together we find that with "short no treatment" 13 out of 50 return and with "long no treatment" 6 out of 50 return. Statistically there is no significant difference. However, if the trend of difference were continued to 100 patients the following figures emerge: with "short no treatment" 26 out of 100 return and with "long no treatment" 12 out of 100 return. The difference now becomes statistically significant, favouring "long no treatment."

There are other criticisms of his paper. Firstly, taking the last two columns again, it may be expected that "short no treatment" would not encourage patients to return-the patient might say to himself, "Why bother? He was completely unhelpful." Thus "short no treatment" might contain a group who did not return because of dissatisfaction. Secondly, Dr Thomas uses return visits to measure outcome. Surely the patient's view of the consultation must be part of the measure of outcome. Rating scales are available for this purpose.

It would have been easier to accept Dr Thomas's report if he had been more cautious in his conclusions. The subject still awaits clarification.

School of Clinical Medicine
Addenbrooke's Hospital,

B B ReISS

Cambridge

\section{Treatment of migraine}

SIR,-Dr David Thrush (7 October, p 1004) states that "referral to the psychiatrist rarely helps [in the treatment of migraine] and may unmask yet more problems." Nevertheless, he considers that "successful treatment depends on correct diagnosis, treating the patient as well as the disease, and spending time talking to the patient-a most neglected therapeutic weapon."

Had he included in his list of essential prerequisites to successful therapy the need to provide a ready ear to the patient's statements he would have clearly indicated his respect for the psychiatric treatment "which rarely helps." He suggests that patients who are refractory to treatment "are best treated with psychotherapy from the general practitioner, who knows both the patient and his background well"- -surely an acknowledgment of the value of psychiatric treatment even if practised by the GP.

Certainly referral to a psychiatrist "may unmask yet more problems," but surely this is very necessary in the management of a painful and disabling entity of obscure aetiology notoriously unresponsive to drugs and frequently precipitated by neurotic factors. Dr Thrush is more psychiatrically minded than he appreciates and should not be reluctant to refer his migraine patients for psychiatric investigation. The outcome may surprise him.

ELLIS Stungo

Felbridge, Surrey

SIR,-In his article on the treatment of migraine in Personal Therapeutics 7 October, p 1004) Dr David Thrush says that ergotamine has never to his knowledge been shown to be more effective than a placebo in a doubleblind trial. Although oral ergotamine has not been shown to be better than a placebo in some trials, ${ }^{12}$ it has in a sequential trial which used a $5 \mathrm{mg}$ oral dose. ${ }^{3}$ Inhaled ergotamine, which Dr Thrush does not find helpful, has been shown to be superior both to an inhaled placebo and to a sublingual preparation. ${ }^{1}$

There is considerable difficulty in evaluating the place of ergotamine in the treatment of migraine. Preparation, route, timing, dose, and selection of patients may all be important. It seems to me unlikely that clinical experience will sort out all these variables and further randomised trials are desirable. The discrepancies in the literature, and the paucity of evidence from randomised trials, on the value of ergotamine are surprising in a condition as prevalent as migraine.

W E WATERS

Department of Community Medicine,

University of Southampton

Crooks, J, Stephen, S A, and Brass, W, British Medical Fournal, 1964, 1, 221.

2 Waters, W E, British Medical fournal, 1970, 2, 325. 1961, 241, 192 .

\section{Drug treatment of psychiatric patients in general practice}

SIR,-May I please be allowed to make the following points following Dr Peter Tyrer's article (7 October, p 1008)?

Academic medicine, pharmacological principles, etc, etc, are a means to an end, not an end in themselves. What matters is that patients get better, and in these times of scarce resources the greatest good is done with the least cost. General practitioners all have a horde of chronically depressed and anxious patients who are a constant source of work and difficulty. These patients require regular support and often regular drug treatment, without which their lives (and ours) are made a misery. Dr Tyrer suggests (he by no means proves) that they are being incorrectly prescribed to by their general practitioners. In whose opinion, pray? Dr Tyrer has judged that the various treatments are incorrect "on pharmacological grounds," but did he ask the patients how often their GPs had tried to get them off medication only to be pleaded with to let them continue with their treatment ?

The proof of the pudding is the fact that 